\title{
AN ECOFEMINIST READING OF TERE LIYE'S SI ANAK PEMBERANI
}

\author{
Yulia Nelfita, Noni Andriyani, Yenni Hayati \\ Universitas Negeri Padang, Indonesia \\ Email:Yulianelfita16@gmail.com,2Noniandriyani@edu.uir.ac.id, \\ 3yennihayati@fbs.unp.ac.id
}

\begin{abstract}
This study is motivated by several reasons, and one of them is the lack of ecofeminist studies of Indonesian novels. The previous studies focus on novels written by women. Ecofeminist studies of Indonesian novels written by men have not been available so far. The analysis in this study is descriptive with hermeneutic technique of interpretation. This is part of a collective research project in this area. The study leads to a conclusion that Tere Liye's novel, Si Anak Pemberani, contains some ecofeminist values. The most represented ones in the text are the natural ecofeminist values because there is essential relationship between women and nature. The least represented ones are the spiritualist ecofeminist values because the relationship between spirituality and nature is considered a mystical belief that is no longer relevant in modern society.
\end{abstract}

Keywords: Ecofeminism, Natural Ecofeminism, Socialist Ecofeminism, Spiritualist Ecofeminism, Novel Tere Liye

\begin{abstract}
ABSTRAK
Penelitian ini dilatarbelakangi oleh beberapa hal; salah satunya adalah belum adanya kajian ekofeminisme terhadap novel-novel Indonesia. Penelitian-penelitian yang sudah pernah dilakukan selalu dilakukan terhadap novel-novel yang ditulis oleh pengarang perempuan sementara penelitian ekofeminisme terhadap novelnovel Indonesia yang ditulis oleh laki-laki belum ada. Berdasarkan hal tersebut, masalah yang dideskripsikan dalam penelitian ini adalah "Bagaimanakah perspektif ekofeminis tercermin dalam novel Si Anak Pemberani karya Tere Liye?". Teori yang digunakan adalah teori ekofeminisme yang meliputi (1) ekofeminisme alam, (2) ekofeminisme spriritualis, dan (3) ekofeminisme sosialis. Penelitian ini bersifat kualitatif dan merupakan penelitian kepustakaan. Metode analisis yang digunakan adalah metode deskriptif yang didukung oleh teknik hermeneutik. Hasil penelitian menunjukkan bahwa terdapat perspektif ekofeminis dalam novel Si Anak Pemberani karya Tere Liye. Aliran ekofeminisme yang dominan adalah aliran ekofeminisme alam karena pada dasarnya perempuan memiliki kedekatan dengan alam. Aliran yang paling sedikit ditampilkan adalah aliran ekofeminisme spiritualis karena pada zaman sekarang kedekatan secara spiritualis dengan alam dianggap hal mistis yang tidak lagi dipercayai oleh masyarakat.
\end{abstract}

Keywords: Ekofeminisme, Ekofemnisme Alam, Ekofeminsime Sosialis, Ekofeminisme Spiritualis, Novel Tere Liye 


\section{INTRODUCTION}

Literary works are works that can be a used as a means to practice communicative language skills. In addition to this benefit, literature can also increase knowledge about human experiences and encourage a successful personality development. Literary works have long been used as reflections or mirrors of nature and society. Therefore, the world of literature continues to develop through ages. The universe contains all existences on earth. Everything on earth is natural for humans to manage. In fact, everything was perfectly created by the Almighty. It is the duty of humankind to protect and preserve the environment. However, the reality is that in recent decades nature is no longer friendly to humans. This situation occurs because of the greed of some humans, who put themselves before the safety of nature and humans themselves. Human greed and selfishness have polluted the surrounding environment. Human selfishness with a belief that human owns the earth makes nature experience instability.

Exploitation activities such as sand mining, deforestation for oil palm cultivation and fishing using trawl. The amount of mining that occurs will have an adverse impact on the environment. If mining continues, erosion will also continue to occur. The potential for landslides is very clear; there are a lack of water discharge and damaged roads.

Problems that occur in natural environment are usually studied in geography and land sciences, but currently, environmental problems are studied by almost all fields of science, including literature. In literary activities, there are several fields of study that link literature and the environment, such as ecological literature and ecofeminism.

Endraswara (2016: 5) states that ecological literature is a literary understanding that seeks to capture ecological messages. Ecological literature in a feminist movement promotes equality in saving the environment, a movement that seeks to protect and preserve nature and the environment on the basis of femininity. It represents women who try to manage or at least tend the comfort and the beauty of the natural environment (Erlanda in Endraswara, 2016: 35).

Ecofeminism addresses numerous problems on earth on the basis of the assumption that women and nature are inseparable. As a movement, it raises the awareness of human's relationship with nature and forms of oppression that are perpetrated by men. Ecofeminism serves as a medium to answer questions about all things on earth and is closely related to nature and women.

Tong (in Wiyatmi, Suryaman, \& Swatikasari, 2017: 5) states that ecofeminism is a thought and a social movement that connects ecological issues to women. Ecofeminism was introduced by Francoise d 'Eaubonne in his work Le Feminisme ou la mort (Feminism or death) which was first published in 1974. Ecofeminism becomes a school of thought that attempt to answer all questions related to the environment. Therefore, eco-feminism also deals with all forms of human oppression. Ecofeminism holds a belief that women are culturally associated with nature. There are several novels that represent or contain ecofeminist ideas in them. A number of researches inform that these novels re-describe phenomena that take place in society, including natural and environmental crises, both directly and indirectly.

Tarigan (in Purba, 2010: 62) states that novel comes from a Latin word, namely noveltus. This word is derived from the word noveis, which means new. It is considered new when compared to poetry and drama. Nurgiyantoro (in Purba, 2010: 62) explains that the term "novella" means a work of fictional prose which is neither too long nor too short.

Building on the initial assumption about Tere Liye's novel titled Si Anak Pemberani mentioned previously, the writer of this study aims to explore ideas or messages in the novel that represent ecofeminist perspectives. The following quotation is an example of an ecofeminist message in the text of Si Anak Pemberani:

"This is my plan for the last four days, to sabotage the sand mining operation by deflating the tires of the truck. It is trivial and may not have much effect. But that's better than just nagging. At least our plan is to send a symbol of resistance to them (Tere-Liye, 2018: 153)".

The novel excerpt above tells about Eliana and some of her friends who put up a resistance to sand mining operations in her village. They don't want to just stand by and watch the mining process takes place. Therefore, they try to protect their village from its exploitation. Eliana has big enough influence to drive away sand miners from her village. 
Building on the aforementioned rationale and phenomena, the writer is interested in conducting a study with the title "An Ecofeminist Reading of Tere Liye's Si Anak Pemberani". The choice of this topic is motivated by three reasons. First, there are still few studies of ecofeminist ideas in literary works. Second, to address the gap in ecofeminist literary studies in Indonesia. There have been ecofeminist studies of Indonesian novels, but most of them examine novels written by female authors. Therefore, the writer intends to discover how ecofeminist ideas expressed in a novel written by a male author, i.e. Tere Liye. Third, this study can make a useful contribution since women's issues are still a relevant topic of discussion in various contexts.

\section{Ecofeminism}

Ecofeminism describes the relationship between women and nature. This field of study is an amalgamation of ecology and feminism. It is closely related to the importance of women's role for the environment. Women are very in control of their roles and positions in their effort to protect and preserve the natural environment. Therefore, its emergence has encouraged creative ideas from nature lovers with their enthusiasm in raising awareness of the importance of nature for survival.

Candraningrum (2014: 3) explains that the presence of ecofeminism etymologically began in 1970 and 1980 as a result of slices and theories in feminism. Ecofeminism not only links women to the environment but also to their spirituality. The destruction of the earth and natural crises are the issues that eco-feminism cares about.

Darmapoetra (in Endraswara, 2016: 35) informs that the third wave of feminism seek to provide explanations the relationship between nature and women with a particular concern on issues related to the destruction of nature by men and its association with women's oppression. Therefore, ecofeminism and the third wave of feminism share the same approach to the studies of the relationship between women and nature.

Tong in Wiyatmi (2017: 8) states that literary ecofeminism has developed into three types of ecofeminism explained below.

1. Natural eco-feminism was developed by Mary Daly in her books Gyn/Ecology and Susan Griffin in Woman and Nature: The Roaring Inside Her.
Natural eco-feminism views nature and women as equal. Women's relationship with nature is even able to encourage life improvement better than men's relationship with nature, and it includes improvements in cultural and traditional values (Tong in Wiyatmi et al., 2017: 8). Natural eco-feminism that is related to tradition or culture highlights women's important capability of caring and nurturing (Endraswara, 2016: 41).

2. Spiritualist eco-feminism was developed by Starhawk and Charles Spretnak. This ism tries to justify the harm that humans cause to nature. Spiritualist eco-feminism views environmental damage from the perspective of patriarchal spirituality (Tong in Wiyatmi et al., 2017: 14). The works of nature and works of women are parallel (Endraswara, 2016: 36).

3. Socialist eco-feminism seeks to eliminate all forms of oppression that occur in the relationship between women and nature. Women should motivate and work together against capitalist patriarchy (Tong in Wiyatmi et al., 2017: 14).

In other words, there are three schools of ecofeminism, namely the natural eco-feminism, the spiritualist ecofeminism, and the socialist ecofeminism. Natural eco-feminism suggests that women are part of nature and continue to perceive womennature relationship on the basis of biological and psychological frameworks. Spiritualist ecofeminism emphasizes that God gives man power over the earth and that man has a very close relationship with the environment. Socialist eco-feminism seeks to debunk such emphasis on the natural relationship between man and the environment.

\section{Ecofeminism as A Linkage Between Ecology and Feminism}

Endraswara (2016: 5) states that ecological literature is a pillar of literary understanding that seeks to capture ecological messages in literature. There are four pillars of literary ecology that need to be mentioned here. The first is the application of the concept of ecology in literary studies by treating the earth (nature) as the center of its studies. The second is the studies of literary works as texts that portray current ecological conditions. The third is the 
studies of certain receptions of environmental literary works. The fourth is the observation on the role of the environment in literary creation. The existing studies of literary ecology has been trying to explain the relationship between literature and the physical environment.

Women must have many ways to continue to care for the environment around them. They must also be able to unite these activities as a form of ecological movement that will later be able to overcome ecological problems that exist around them. Feminists must be able to show that humans have a way to protect what needs to be maintained and to make positive changes to the environment.

Tong (in Wiyatmi et al., 2017: 6) states that ecofeminism seeks to show the relationship between all elements especially women and nature. It seeks to show the relationship that occurs between all forms of human oppression, especially oppression of women and nature itself. Ecofeminism holds that women can be conceptually associated with nature in addressing ecological issues.

\section{Ecofeminism as one of the schools of feminism}

Ecofeminism is a school that creates a movement to protect the environment. Women are required to take an active role in protecting the environment. Eco-feminism also provides an understanding of the relationship between all forms of women's oppression. It is humans' duty to make themselves aware that nature should be treated as a very valuable treasure.

Tong (in Wiyatmi et al., 2017: 6) argues that ecofeminism understands not only the relationship between humans, but also between humans and nonhuman species, namely animals and plants. In this connection, humans often replace natural resources with machines and pollute the environment with poisonous gases. Therefore, natural eco-feminism's mission is to fight for their sustainability.

\section{FINDING AND DISCUSSION}

\section{Natural Ecofeminism}

Natural eco-feminism views nature and women as equal. Women are even able to encourage a better life and harmonious relationship more than men can do, including the preservation of cultural and traditional values. Tong (in Wiyatmi et al., 2017: 8) states that natural eco-feminism is closely related to cultural and traditional values. This can promote better and more sustainable social relationships.

Endraswara (2016: 41) states that natural ecofeminism believes that traits that are traditionally associated with women, such as caring, nurturing and intuitive, are not the result of cultural construction but the product of women's biological and psychological experiences. In Tere Liye's novel titled Si Anak Pemberani, 15 parts of the text can be identified as the representations of natural ecofeminist values. In the following sections, 15 excerpts of those representations from the text are discussed respectively as data $1,2,3,4,5,6,7,8,9,10,11,12,13$, 14 , and 15 in their connection to natural ecofeminist values.

\begin{tabular}{l|l} 
Data 1 & $\begin{array}{l}\text { But mamak reminded them of their } \\
\text { promise to help pick mangosteen in the } \\
\text { garden (Tere-Liye, 2018: 3). }\end{array}$
\end{tabular}

Data 1 is considered to represent a natural ecofeminist idea of the close relationship between women and nature. Women and nature are represented in the word mamak and alam respectively. Their relationship is indicated by the part of the sentence "picking mangosteen in the garden". In the story, data 1 tells about a mother who recalls that her sons, namely Pukat and Burlian, promise her to help her pick mangosteen in the garden. This shows that the mamak figure wants to instill a sense of responsibility in Pukat and Burlian by expecting them to keep their promise to help their mamak pick mangosteen in the garden. In addition, mamak also teaches their children to participate in working in the garden in the hope that they can develop their physical strength.

Gardening activities provide opportunities for children to explore and observe their surroundings. Children need to be given the freedom to develop their imagination, use the right tools to learn and play, train their intelligence and foster their sense of responsibility (Herdaining, 2014). Thus, the mamak has taught their children a sense of responsibility. Mamak's love for gardening signify a woman's close relationship with nature, and she passes it down to her children. 
Data 2 We are poor. This shirt is also warp. Purchased at a flea market. My father never sold my entire village to you (TereLiye, 2018: 15).

Data 2 represents natural ecofeminist attitude in the form of women's rejection of inferiority in their defense of the preservation of nature. "We" in the above excerpt refers to Eliana and Amelia, and they represent women in society. "My village" represents the nature or the environment. The context of this excerpt is that the character named Eliana struggles to prevent sand miners from entering her village. She expresses that he father would never sell the village although they are poor.

Eliana carries out one of her duties as a human being, which is to continue protecting the village by not allowing sand miners exploit the natural resources in there. Eliana's situation is similar to what happened in reality in Tumpang Pitu area, namely the resistance against mining which took place from 2017 to 2018 . Women participated in the actions of resistance against mining in Tumpang Pitu during that period. The resistance was reasonable since women would be impacted the most impact by its operation especially in the economic aspect of their daily life (Saputra, 2018: 8). Thus, women have the rights to voice and express opinions. Eliana is one of these women, those who dare to take action against things that can harm their village.

Data 3 You guys remember this, I really remember all those incidents, long ago I hated them, dozens of trucks going back and forth, heavy equipment scooping up river sand (Tere-Liye, 2018: 16).

Similar to Data 2, Data 3 conveys a natural ecofeminist message in the form of women's rejection of inferiority in their defense of the preservation of nature. In this data-3 excerpt, "I" refers to Eliana and thus represent women. "Sungai Pasir" represents nature. Data 3 tells about Eliana's deep resentment towards the sand miners who enter her village. She hates dozens of trucks and heavy equipment (the river sand extractors) go in and out of her village. Eliana does not want the river that provides water to the villagers to be polluted by sand miners. This is similar to the sand mining issue in reality that took place in Serayu river, in Kemangkon village. The sand dredging activities in 2019 and disrupted local activities. About 200 women from the village held a demonstration to protest against the sand mining in their village (Fajar, 2019: 1). In fact, the number of environmental problems is increasing, and women play an important role in the efforts to save the environment. Eliana in $\mathrm{Si}$ Anak Pemberani plays an active role in fighting for her village by protesting against sand mining operation in there as her effort to preserve the environment in which she lives.

\begin{tabular}{l|l} 
Data 4 & $\begin{array}{l}\text { They could have sent dozens of trucks. We } \\
\text { all understand that rivers, forests, valleys } \\
\text { do not legally belong to us. For this we } \\
\text { must be smart and resilient and have the } \\
\text { endurance against them (Tere-Liye, 2018: } \\
\text { 19). }\end{array}$
\end{tabular}

Data 4 contains a representation of natural ecofeminist idea about the close relationship between women and nature. "We" in the above excerpt refers to Bapak, Amelia and Wak Yati, and it represents women. "forest", "river" and valley represent nature. In the novel, this part of the story tells about Eliana's persistence in protecting the rivers, the forests and the valleys in her surroundings. Eliana insists that Amelia and Wak Yati continue to be resilient and have endurance against sand miners. Based on the data above, Eliana is a woman who is persistent in protecting rivers, forests and valleys from the sand miners in her village.

Steward (in Endraswara, 2016: 70) states that women must be able to take good care of nature and the environment, as expressed by a character from Wonosari that the environment must be well preserved and maintained. Therefore, it can be seen clearly that Eliana is someone who is very close to nature. Eliana hopes that Bapak, Wak Yati and Amelia have the same vision, namely to continue to protect the existing legacy in their village which means maintaining their resilience in dealing with sand miners.

Data 5 Already helping mamak in the kitchen. It has finished my part of the woven (TereLiye, 2018: 56). 
Data 5 presented above is also a representation of natural ecofeminist idea of the direct relationship between women and nature. Women in the Data 5 excerpt are represented by mamak, whereas nature is represented by the word "woven." The excerpt is part of the story that tells about Eliana's role in helping mamak with the chores in the kitchen, which is finishing the weaving. This part represents women's closeness to nature. In the story, Eliana uses rattan to make wicker.

Fidiatmoko (2017: 3) states that woven material is an inanimate object which is closely related to daily life, often perceived as an aesthetic handicraft. The webbing becomes attractive during the process of weaving ribbons. Daulay and Nurmaniah (2019) mentions that one of the activities that can improve fine motor skills is weaving because weaving requires the coordinated movement of eyes and hands to train accuracy and patience. The activity of weaving brings many benefits and of course brings the weaver closer to nature, just like what Eliana did in the story.

\begin{tabular}{l|l} 
Data 6 & $\begin{array}{l}\text { After school, the four of us were told to } \\
\text { help mamak make ground coffee. The } \\
\text { coffee cherries are dried in the sun to dry } \\
\text { for several days. Then they are roasted } \\
\text { for hours until they turn black (Tere-Liye, } \\
\text { 2018: 100). }\end{array}$
\end{tabular}

Data 6 here contains another part of the text that represents the natural eco-feminist idea of women's close relationship with nature. "We" refers to Eliana, Amelia, Pukat and Burlian, and they are all together a representation of women. The phrase "Coffee fruit" certainly represents nature. The excerpt shown as Data 6 above tells about the mamak who gives them the responsibility of helping her make ground coffee from coffee cherries. The work involves picking, drying and roasting for several hours until the coffee turns black.

Panggabean (2012: 1) states that coffee fruit is a type of plant that grows in tropical climates. Coffee fruit can be processed into drinks that do not contain alcohol but contain caffeine. There are many benefits one can obtain from consuming coffee, including an increase in the body's metabolism. Hanafi (2016: 2) states that caffeine can reduce kidney stones and gallstones. A study on 81,000 women who were treated to drink $200 \mathrm{ml}$ of coffee or about one cup per day reported a $10 \%$ reduction in the risk of kidney stones in them. Mamak in the story has taught her children how to process coffee cherries into ground coffee. This coffee processing activity shows Mamak's closeness as a woman to nature, and she wants to transmit this value to her four children.

Data 7 So without thinking anymore, forgetting about the big crocodile who lives in the basin of the prohibition, I slide on the river rock, thudding softly to touch the water (Tere-Liye, 2018: 159).

Data 7 presents another part of the text that represents the natural ecofeminist idea of womennature relationship. Women are represented in "I," the pronoun which refers to Eliana. Nature is represented in the phrase "river rock." This part of story tells about Eliana's effort in trying to get the sand miners out of her village. The sand miners catch Eliana spying on them, and it makes her hurry to a river rock. For Eliana, the river is the greatest gift that must be guarded at any time because the river is a water resource for the villagers. It has also been a playground for the children in its vicinity.

Pratiwi in Candraningrum (2014: 70) describes that a river is a living thing and needs to be loved. Its health depends on the quality of the environment and its ecosystem. In the novel, Eliana takes care of nature, and in return, nature takes care of Eliana. The excerpt indicates that Eliana is hiding between the river rocks and not worrying about the big crocodile that lives in that area. This reflects Eliana's close relationship with nature. Eliana and nature take care of each other.

$$
\begin{array}{l|l}
\text { Data } 8 & \begin{array}{l}
\text { Because now there are four of us, it is } \\
\text { easier to stalk the sand mine. We arrange } \\
\text { a schedule, taking turns (Tere-Liye, 2018: } \\
\text { 168). }
\end{array}
\end{array}
$$

Data 8 represents natural ecofeminist rejection of women's inferiority to nature. "We" in the excerpt above refers to Eliana, Hima, Marhotap, Damdas, and they represent women. "Sand mine" represents nature. In the novel, this part of the story tells about their action of planning a stalking the sand mine. They arrange a schedule to spy on the miners in turn. Similar to the case of resistance to the Mount Tumpang Pitu Mining in real life, the resistance was organized 
by women who were worried about the mining's negative impact on their living environment because the mine site was located too close to the residential area (Saputra, 2018: 19). Kuspriyanto (2016: 203) states that the rampant sand mining activity will result in social problems for the community, especially for those living around the sand mining area. Women play an important role in the efforts to resist sand mining operation in their environment. They are aware of the bad its impact on nature. This is what is exemplified by Eliana and her friends, Hima and Marhotap in $\mathrm{Si}$ Anak Pemberani. They hope that their action will stop the mining operation in their village.

\begin{tabular}{l|l} 
Data 9 & $\begin{array}{l}\text { Marhotap laughed, pulling something } \\
\text { out of his pants pocket, "If it were only to } \\
\text { fill the tires of their trucks, we wouldn't } \\
\text { have to storm the sand delta, Eli." See! in } \\
\text { Marhotap's hands lay a dozen large nails. } \\
\text { (Tere-Liye, 2018: 171). }\end{array}$
\end{tabular}

Data 9 also contains the part of the text that represents natural eco-feminist rejection of women's inferiority to nature. Women in the quoted excerpt above are represented by the word "we" which refers to Eliana and Marhotap. Nature is represented in the phrase "delta sand." This part tells about one of Eliana and Marhotap's actions in disrupting the sand mining activities. They plan to puncture the tires of the sand mining trucks with dozens of nails.

Delta is a landform at the mouth of large rivers that is created by deposition of sediment transported by rivers (Departemen Pendidikan Nasional, 2008). Naturally, the river delta and its natural heritage must be preserved. Eliana and her friends are the brave characters in the story. They will continue to fight for what they feel is right. They are willing to put up resistance to anybody or anything that might harm their village such as the sand mining operation. Nature must be constantly preserved because it supports lives on Earth especially humans.

$$
\begin{array}{l|l}
\text { Data } 10 & \begin{array}{l}
\text { I used to also often play in the forest } \\
\text { (Tere-Liye, 2018: 182). }
\end{array}
\end{array}
$$

Data 10 is another natural ecofeminist idea of women's close relationship with nature. The word "I" that refers to "Nek Kiba" represents women, whereas the word "forest" represents nature. The excerpt presented as Data 10 above tells about a woman named Nek Kiba. A long time ago Grandma Kiba had a habit of going to the forest to see the plants and animals in there. This habit demonstrates Grandma Kiba's love for the forest. Playing in the forest can be beneficial for our health. it has been reported that one day trip in the forest can cause an increase in NK cells and prevent cancer. In addition, the smell of the forest can reduce the risk of stress. According to the Global Burden of Disease Study, nearly 30\% of the world's population is obese. In the UK, $57 \%$ of women are in the category of overweight. Walking or cycling in the forest would help with weight loss (Wahyuningsih, 2015: 2). Therefore, Nek Kiba's activities of playing in the forest in the past are a healthy habit as well as a good portrayal of a woman bonding with nature. Therefore, women and all non-human aspects in nature cannot be separated and dependent on one another.

\begin{tabular}{l|l} 
Data 11 & $\begin{array}{l}\text { I've been learning to weave songket for } \\
\text { two months with Wak Yati (Tere-Liye, } \\
\text { 2018: 193). }\end{array}$
\end{tabular}

Data 11 above contains part of the text that represent the natural eco-feminist idea of women's close relationship with nature. The word "I" that refers to Eliana represents women, whereas the word "songket" represents nature. The Data 11 excerpt tells about Eliana who learns to weave songket for two weeks from Wak Yati. Devi (2015: 10) states that weaving songket is one of the many weaving creations produced in various regions in Indonesia. Weaving songket is not as easy as it seems. It is quite complicated and requires high concentration since precision and persistence are important in operating a loom to weave. Women who work as a weaver and produce weaving crafts can either make it their main livelihood or do it as a side job. The character named Wak Yati in the story has taught Eliana to weave as her effort of pass her weaving skills down to Eliana. This weaving activity shows Wak Yati and Eliana's closeness to nature.

\begin{tabular}{l|l} 
Data 12 & $\begin{array}{l}\text { When you grow up. Just count the fingers } \\
\text { of the person who can weave the songket. } \\
\text { So be proud of this skill (Tere-Liye, 2018: } \\
\text { 197). }\end{array}$
\end{tabular} 
The part of the text in Data 12 represents the natural eco-feminist idea of women's close relationship with nature. "Kamu" in the excerpt above refers to Eliana, and Eliana represents women. "Songket weaving" represents an interaction with nature. In the novel, this part tells about Wak Yati who expresses her vision that in the next few years there will only be very few women with weaving skills. She encourages Eliana to be proud of the songket weaving skills she is learning. Besides songket weaving can also give an economic benefit. Nurcahyani (2018: 5) states that weaving or songket tradition is found well preserved only in several areas in West Kalimantan and Pontianak. In fact, in the current era of globalization, there have been many shifts in cultural values. Many young people have moved away from the traditions they once adhered to (Rahayu \& Alber, 2019: 91). With Eliana still actively learning to weave with Wak Yati, Wak Yati hopes that Eliana will be part of the new generation that help preserve songket weaving skills as a cultural heritage. This literary representation highlights that women are very close to nature and have the power to protect the existing cultural and natural heritage.

\begin{tabular}{l|l} 
Data 13 & $\begin{array}{l}\text { And he was kind enough to teach us how } \\
\text { to survive if we got lost in the forest. He } \\
\text { also introduced the names of plants and } \\
\text { explained their uses, invited us to see wild } \\
\text { animals and observe their activities (Tere- } \\
\text { Liye, 2018: 242). }\end{array}$
\end{tabular}

Data 13 presents the next part of the text that represents the natural eco-feminist idea of women's close relationship with nature. Women are represented in the word "us" which refers to Eliana and Amelia, whereas nature is represented in "the forest," "plants" and "wild animals." This part tells about a character named Uncle Unus who, with his kindness, take Eliana and Amelia for a walk into the forest, teaching them the knowledge about how to survive in the forest. He introduces the names of plants in the forest and their uses. He also shows them some wild animals and their behaviors so that one day if they want explore the forest by themselves they would know which ones are wild animal.

Falemer (in Candraningrum, 2014: 77) explains that a forest is a place where various kinds of plants and animals live and be part of it. Forests are crucial for the survival of animals and plants (Andriyani, 2020: 6). Thus, Uncle Unus's action of taking Amelia and Eliana for a walk in the forest proves his love for nature and his hope that one day Eliana and Amelia will have the same love for and closeness to nature as he does.

\begin{tabular}{l|l} 
Data 14 & $\begin{array}{l}\text { Eli is even happy even though she is only } \\
\text { invited to the forest (Tere-Liye, 2018: } \\
258) .\end{array}$
\end{tabular}

Data 14 presents the next part of the text that represents the natural ecofeminist idea of women's closeness to nature. "Eli" represents women, whereas "forest" represents nature. This part of the story tells about Eliana who likes to be invited to walk through the forest accompanied by Uncle Unus. Setiawan (2016: 2) states that so far, there are still few women who are happy to participate in outdoor activities in the forest. This is not the case with Eliana, who is pleased to visit the forest with Unus. Evidently, Eliana develops a close relationship with nature.

\section{Data 15 I want to be a defender of truth. Defenders of threatened environments. Defenders of our villages, our forests, rivers, valleys (Tere-Liye, 2018: 356).}

Data 15 presents another part of the text that represents the natural ecofeminist idea of women's close relationship with nature. Women are represented by the word "I" that refers to Eliana, and nature is represented in the word "Kampung." Data 15 excerpt shows Eliana's determination to become a woman who defends the truth as well as the environment that is under threat in her village. She makes a promise to protect the natural resources in the village - the forests, the rivers and valleys-no matter what. Bourdieau in Endraswara (2016: 54) states that the importance of saving the environment is based on moral responsibility. Eliana is a moral woman who really cares about the truth and the environment. She is even willing to sacrifice anything to defend the environment in her village. This shows Eliana's closeness to nature.

\section{Spiritualist Ecofeminism}

Spiritualist eco-feminism was developed by Starhawk 
and Charles Spretnak. This school of ecofeminism tries to justify the harm that humans cause to nature. Spiritualist eco-feminists understand environmental damage with a patriarchal spirituality (Tong in Wiyatmi et al., 2017: 14). Nature's work and women's work are the same (Endraswara, 2016: 36) Spiritualist eco-feminism has three core concepts, namely (1) immanence (immanence), (2) interconnection (interconnected), and (3) compassionate-lifestyle (lifestyle) . In Si Anak Pemberani by Tere Liye, there are 15 parts of the text are taken as the data (excerpts) that contain ecofeminist perspectives or ideas. Of all the data, there is only one piece of data that represents a spiritualist ecofeminist idea, namely Data 7. As mentioned previously, Data 7 presents the following excerpt.

So without thinking anymore, forgetting about the big crocodile who lives in the basin of the prohibition, I slide on the river rock, thudding softly to touch the water (Tere-Liye, 2018: 159).

The data above contains part of the text that represents a spiritualist eco-feminist idea that women are aware of the forces of nature. Women are represented in the word "I." It refers to Eliana. Nature is represented in the phrase "river rock." In the novel, this part of the story tells about Eliana's struggle make the sand miners leave her village. Eliana rushes behind a rock in the village river in order to avoid being chased by the sand miners. In doing so, she runs the risk of encountering the large crocodile that dwells in the river, in the prohibited area. The prohibited area of the river-the lubuk prohibition-is believed by the villagers to contain supernatural powers. This belief in the supernatural can also be found in the real world such as that in the Martapura Banjar river. The locals believe that there are yellow crocodiles dwelling in Martapura river with their supernatural power (Didi, 2018: 1). In the story, Eliana, as a member of her cultural group of the village, believes that the large crocodile dwelling in the lubuk prohibition, is part of the natural power that has been a symbol in her village.

\section{Socialist/Transformative Ecofeminism}

Socialist eco-feminism seeks to remove the emphasis on the relationship between women and nature. Women should motivate and work together against capitalist patriarchy and other isms (Tong in Wiyatmi et al., 2017: 14). Socialist eco-feminism is considered to be more comprehensive by turning to transformative feminism. Transformative eco-feminism has 6 characteristics, namely (1) it recognizes the bond between all operating systems, (2) it emphasizes the diversity of women's experiences, (3) it rejects the logic of domination, (4) it explores what it means to be human and continuously build awareness, (5) it depends on ethics that emphasizes the values of feminism, and (6) it argues that science and technology are only used to maintain the continuity of the earth (Starhawk in Endraswara, 2016: 36). Of the 15 data taken from the text of the novel Si Anak Pemberani, two data are identified as parts of the text that contain transformative eco-feminist idea, namely Data 12 and Data 15.

\begin{tabular}{l|l} 
Data 12 & $\begin{array}{l}\text { When you grow up. Just count the fingers } \\
\text { of the person who can weave the songket. } \\
\text { So be proud of this skill (Tere-Liye, 2018: } \\
\text { 197). }\end{array}$
\end{tabular}

The excerpt above represents a socialist ecofeminist message about continual rethinking of what it means to be human by building consciousness. As mentioned earlier, this part tells about Wak Yati who expresses her vision that in the next few years there will only be very few women with weaving skills. Wak Yati is well aware of the need to pass the skills down to Eliana to prevent them from extinction. Wak Yati hopes that Eliana will be part of the new generation that help preserve songket weaving skills as a cultural heritage. Her decision to teach Eliana to weave songket is also motivated by her awareness of the importance of creative skills for a woman.

Data $15 \mid \begin{aligned} & \text { I want to be a defender of truth. Defenders } \\ & \text { of threatened environments. Defenders } \\ & \text { of our villages, our forests, rivers, valleys } \\ & \text { (Tere-Liye, 2018: 356). }\end{aligned}$

The excerpt in Data 15 above also represents a socialist eco-feminist message about continual rethinking of what it means to be human by building consciousness. This part of the story tells about Eliana's determination to become a woman who defends the truth as well as the environment that is under threat in her village. She makes a promise to protect the natural resources in the village-the forests, the rivers and valleys-no matter what. This 
description of Eliana's determination here implicitly conveys the need to defend the environment with full awareness of its importance.

\section{CONCLUSION}

It has been made clear that spiritualist ecofeminist idea is the least represented in the novel. The reason is probably because in this modern era, spiritualist approach to human's relationship with nature is considered a mystical belief that is no longer relevant in modern society. In conclusion, Tere Liye's Si Anak Pemberani is a novel that invites the readers to understand that protecting nature is every human's responsibility and to believe that if humans protect nature, nature will take care of humans in return.

\section{REFERENCES}

Andriyani, N. (2020). Kritik Sastra Ekologis dalam Drama-Drama Terbaru Indonesia. Jurnal Sastra Indonesia, 9(2), 85-89. https://doi.org/10.15294/ jsi.v9i2.37904

Candraningrum, D. (2014). Ekofeminisme: Dalam Tafsir Agama, Pendidikan, Ekonomi dan budaya (1st ed.). Yogyakarta: Jalasutra.

Daulay, W. C., \& Nurmaniah, N. (2019). Pengaruh Kegiatan Menganyam Terhadap Keterampilan Motorik Halus Pada Anak Usia 5-6 Tahun Di Tk Al-Ihsan Medan T.A 2018/2019. Jurnal Usia Dini, 5(2), 7-19. https://doi.org/10.24114/jud. v5i2.16200

Departemen Pendidikan Nasional. (2008). Kamus Besar Bahasa Indonesia. Jakarta: Pusat Bahasa. (Jakarta).

Devi, S. (2015). Sejarah dan Nilai Songket Pandai Sikek. Jurnal Ilmu Sosial Mamangan, 2(1), 17-28. Retrieved from

https://media.neliti.com/media/publications/103002ID-sejarah-dan-nilai-songket-pandai-sikek.pdf

Didi, Silvia. (2015). Sejarah Dan Nilai Songket Pandai Sikek. Jurnal Ilmu Sosial. Voume 2. Nomer 1. Diakses dari : https://media.neliti.com/media/ publications/103002-ID-sejarah-dan-nilaisongket-pandai-sikek.pdf.

Endraswara, S. (2016). Sastra Ekologis: Teori dan Praktik Pengkajian. Yogyakarta: CAPS (Center for Academic Publishing Service).

Fajar, Jay. 2019. Gerakan Para Ibu Hentikan Penambangan Pasir Sungai Serayu. Diakses di https://www.google.co.id/amp/s/www. mongabay.co.id/2019/09/20/ini-gerakan-paraibi-hentikan-penambangan-pasir-sungai-serayu/ amp/. Agustus 2019.

Fidiatmoko, A. (2017). Menganyam Rupa (Undergraduate Thesis, Institut Seni Indonesia Yogyakarta). Institut Seni Indonesia Yogyakarta, Yogyakarta. Retrieved from http://lib.isi.ac.id

Hanafi, Indri. Manfaat dan Kerugian Minum Kopi. Diakses. di: https://lampung.kemenag.go.id/files/lampung/ fie/file/artikel/tpix1460429134.pdf.

Kuspriyanto. (2016). Dampak Penambangan Galian C (Pasir) di Pinggiran Sungai Brantas Kecamatan Ngunut Kabupaten Tulungagung. Swara Bhumi, 3(3), 202-212. Retrieved from https://core. ac.uk/reader/230706934

Nurcahyani, L. (2018). Stategi Pengembangan Produk Kain Tenun Ikat Sintang. Jurnal Pendidikan dan Kebudayaan, 3(1), 56-72. https://doi. org/10.24832/jpnk.v3i1.530

Panggabean, E. (2012). Buku Pintar Kopi. Jakarta: Agromedia Pustaka.

Purba, A. (2010). Sastra Indonesia kontemporer. Yogyakarta: Graha Ilmu.

Rahayu, S., \& Alber, A. (2019). Nilai-Nilai Budaya dalam Gurindam Tunjuk Ajar Melayu Karya Tenas Effendy. GERAM, 7(1), 90-100. https://doi. org/10.25299/geram.2019.vol7(1).2878

Setiawan, P. E. (2016). Pengaruh Kewajiban Moral, Kualitas Pelayanan, Sanksi Perpajakan Pada Kepatuhan Wajib Pajak Di KPP Badung Utara. E-Journal Akuntansi Universitas Udayana Vol.17.2, 913-937

Surtani, Herdini Widyaning Pertiwi, Jurnal Kebidanan 2014, Hubungan Antara Postnatal Breast Care Dengan Terjadinya Bendungan ASI di Bidan Praktik Swasta (BPS) Wilayah Kerja Puskesmas Wuryantoro Wonogiri.

Saputra, R. A. (2018). Partisipasi Perempuan dalam Aksi Penolakan Pertambangan Gunung Tumpangpitu (Suatu Analisis Ekofeminisme) (Undergraduate Thesis, Universitas Negeri Jember). Universitas Negeri Jember, Jember. Retrieved from http://repository.unej.ac.id// handle/123456789/88877

Tere-Liye. (2018). Si Anak Pemberani. Depok: Penerbit Sabakgrip.

Wahyuningsih, A. (2015). Cobalah jalan-jalan di hutan dan rasakan 7 manfaat dahsyat ini! Retrieved February 17, 2021, from Brilio website: https:// www.brilio.net/life/cobalah-jalan-jalan-di-hutandan-rasakan-7-manfaat-dahsyat-ini-150608c. html

Wiyatmi, Suryaman, M., \& Swatikasari, E. (2017). Ekofeminisme: Kritik sastra berwawasan ekologis dan feminis. Yogyakarta: Cantrik. 